\title{
アミノ配糖体抗生物質投与の腎毒性の電顕的観察
}

$\begin{array}{ccccc}\text { 済生会神奈川県病院泌尿器科 } & \text { 木 } & \text { 村 } & \text { 茂 } & \text { 三 } \\ \text { 慶応大学医学部泌尿器科学教室 } & \text { 中 } & \text { 薗 } & \text { 昌 } & \text { 明 } \\ \text { (主任: 田崎 寛教授) } & \text { 田 } & \text { 崎 } & & \text { 寛 }\end{array}$

\section{ELECTRON MICROSCOPIC EVALUATION OF THE RENAL TUBULAR DAMAGE IN RATS AFTER AMINOGLYCOSIDE ADMINISTRATION}

\author{
Shigezo Kinura, Masaaki Nakazono* and Hiroshi Tazaki* \\ Department of Urology, Saiseikai Kanagawa-ken Hospital \\ *Department of Urology, Keio University Hospital
}

Nephrotoxity of Sisomicin, a recently developed aminoglycoside, was studied in the sequence of proximal tubular damage and repair after administration of the agent based on light and electron microscopic observations and biochemical evaluations using over 50 Wistar strain rats weighing 200$250 \mathrm{gr}$.

Sisomicine was administered intramuscularly at a dose of either 60 or $100 \mathrm{mg} / \mathrm{kg} /$ day for 7 days continuously and during the first 3 administration days, the animals were kept dehydrated.

The animals were sacrificed on 3, 7, and 12th days to study damage processes in the proximal tubular epithelium and the recovery was evaluated in the animals sacrificed in 2,3 , and 4 th week after discontinuation of the injection. As a control study, Ceftizoxime was administered to rats intraperitoneally at a dose rate either 800 or $1200 \mathrm{mg} / \mathrm{kg} /$ day under the same conditions to those of the experimental series.

The most dramatic and characteristic morphological change in the proximal tubular epithelium after aminoglcosides administration is that myeloid bodies can be observed under electron microscopy.

Appearance of the myeloid bodies has been confirmed a common morphological change in the epithelium after administration of either amphiphilic or cationic amphiphilic agents. Both formation and degenerative processes of the myeloid body were studied through electron microscopic observation.

After aminoglycoside administration, lysosomal enzymes which concern with fat metabolism, namely sphingomyelinase, are kept in inhibitatory conditions, so that it is difficult for the enzymes to digest the substances completely which configurate the myeloid body in a certain period and they are stored in the lysosomes.

Our conclusion is that renal insufficiency develops clinically at the point when the accumulated myeloid body is over the maximum capacity of lysosome. In other words, the accumulation process reaches the stage of lysosomes overloading.

要旨: 新しく開発されたアミノ配糖体抗生物質 Sisomicinの腎毒性について検討した. 実験は体重 200 250g の約50匹の Wistar 系ラットを使用した. Sisomicin 投与時の近位尿細管上皮の障害過程およ び回復過程について光学および電子顕微鏡にて観察, また生化学的検査も施行した。

実験動物は最初の 3 日間は脱水状態にて飼育し，その後は自由に水分を摂取させた. Sisomicin 60 お よび $100 \mathrm{mg} / \mathrm{kg} / \mathrm{day} 7$ 日間連続筋注した. 動物は注射後，3，7，12日目に屠殺して近位尿細管上皮の 障害過程を調べ, また回復過程を調べるため筋注中止後 $2,3,4$ 週目に屠殺した. 対照群として, Ceftizoxime 800 および $1,200 \mathrm{mg} / \mathrm{kg} /$ day 腹腔内注射をして同様の実験を行った.

すべてのアミノ配糖体抗生物質投与時に近位尿細管上皮に出現する, きわめて特徵的な電䫒像はミェ

リン様小体 myeloid body の出現である.

ミェリン様小体はAmphiphilic あるいは Cationic Amphiphilic 薬剤投与時にも出現することが指摘 
されている. ミェリン様小体の形成执よび変性過程について電顕的観察を行った.

アミノ配糖体投与により，膜脂質成分である燐脂質が主に lysosome 内でアミノ配糖体と燐脂質の複 合脂質であるミェリン様小体を形成する。これらは投与量の増加とともに lysosome 内でミェリン様小 体の過形成が括こり, 消化酵素の低下もあり, lysosome overloading の問題が起こり, 細胞内恒常性が 失われ，また一部では lysosome 膜は崩壊しミェリン様小体が上皮細胞内へ放出され，同時に lysosome 酵素が放出されて, 上皮細胞内で自家融解作用を起こし，尿細管壊死をきたし急性腎不全を招来する原 因の一つになると考觉らる。

\section{I. 緒 論}

アミノ配糖体抗生物質（以下アミノ配糖体と略記） は，緑膿菌をはじめ，広く好気性グラム陰性桿菌に強 い抗菌力を持つ抗生物質であるが，副作用として腎毒 性および聴器毒性が強いことが知られている。

薬物の主要排泄経路の 1 つは腎であり，腎では糸球 体の濾過括よび尿細管の分泌，再吸収により薬物の代 謝，排泄が行われている。そのなかで尿細管，特に近 位尿細管上皮の直部 (pars recta) は薬物による変性が もっとも発現しやすい部位とされている。

アミノ配糖体の腎毒性については欧米を中心に数多 くの研究がなされてきているが，電子顕微鏡（以下電 顕と略記）による観察では，すべてのアミノ配糖体投 与時に共通して, 特徵的にみられる所見はミェリン様 小体, myeloid body の出現である. ミェリン様小体と 腎不全との関連については，細胞内異物処理機構とし ての lysosome が overloading となった時点で急性腎 不全が発現するとする考え方" とミェリン様小体の出 現は単にアミノ配糖体投与の指標にしか過ぎず，腎の 有機イオン輸送障害, 系球体滤過值の減少, 排泄機能, 濃縮機能の低下，尿細管機能低下などもっと広い腎生

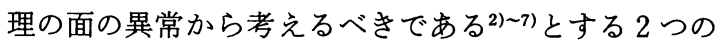
考方方があ。

今回の動物実験ではアミノ配糖体を投与して，腎機 能および腎, 肝, 肺, 大動脈の平滑筋につき, 経時的 変化を主に電顕で観察したが, 本報告では諸臓器にお ける経時的な観察結果のうち, 腎, 特に近位尿細管上 皮の細胞変化を中心にミェリン様小体の発生および消 失過程, 腎障害との関係を考察するとともに燐脂質蓄 積症についても文献的考察を行った。

アミノ配糖体としてはSisomicin（以下 SISO と略 記）を使用した。 SISO は比較的新しい製品であり, Gentamicin (以下 GM と略記) の改良型とされ, 化学 構造式は類似しており, ほぼ同一の作用機序を持つと されている8). また, 対照群として第 3 世代セフェム系 抗生物質 Ceftizoxime(以下 CZX と略記)を使用した。
アミノ配糖体に関する報告は GM に関するものが多 く, 新製品である SISO に関する報告は, ほとんどみら れないので SISO 投与の文献的考察については GM に関する報告を参考にした。

\section{II. 材料および方法}

体重200 250g の wistar 系ラット約50匹を用い, 前 提条件として 3 日間脱水状態にした。これは木村910) が既に報告したように，動物実験において薬物投与に よる腎障害を起こしやすい前提条件は, 脱水, 尿停滞, 腎乏血の順であることがわかっているからである，脱 水開始と同時に 7 日間連続して SISO 群は60mg 拈よ び $100 \mathrm{mg} / \mathrm{kg} /$ day 筋注, CZX 群は $800 \mathrm{mg}$ および $1,200 \mathrm{mg} / \mathrm{kg} / \mathrm{day}$ を腹腔内注射, 注射後 $3 ， 7 ， 12$ 日 目および回復過程をみるため， $2,3 ， 4$ 週目に屠殺 した. 各群とも 2 匹ずつを用いた。すべての動物の主 要藏器はホルマリン固定後, 常法に従って光学顕微鏡 (以下光顕之略記)で観察した。光顕用組織片は $10 \%$ 中 性緩衝ホルマリン固定後, H-E, PAS, Malloly の各染 色を施行した. 電顕の観察は腎, 肝, 肺, 大動脈の平 滑筋について行った. $2.5 \%$ グルタールアルデヒド $(\mathrm{pH}$ 7.4 燐酸緩衝液) で 2 時間前固定, 同緩衝液で洗浄後, $1 \% 4$ 酸化オムミウムで 1 時間固定, 後処理は通常の 方法で行った後, JEM-100B 型電顕で観察した。 また, 電顕組織化学としては, Gomori-Novikoff 変法による Acid phosphatase 反応を施行した。 また，急速凍結置 換固定法 ${ }^{11)}$ を行った。この対照群としては4,4'-diethyl aminoethoxy hexestrol (以下コラルジルと略記)を投 与して，腎，肝につき検索した。

\section{III. 所見}

a）血清生化学的検査

血清生化学的検査では腎機能測定のため, 各群とも 2 匹ずつの平均値をとり, 血清 BUN, Creatinine 值と した. Wistar 系ラットの血清 BUN の平均值は $20 \mathrm{mg} /$ $\mathrm{dl}$ 前後, Creatinine は0.5 1.0mg/dl であり, 表 1 の ようにSISO $60 \mathrm{mg} / \mathrm{kg} /$ day では投与開始後 7日目で は BUN, Creatinine の有意の上昇は認められないが, 

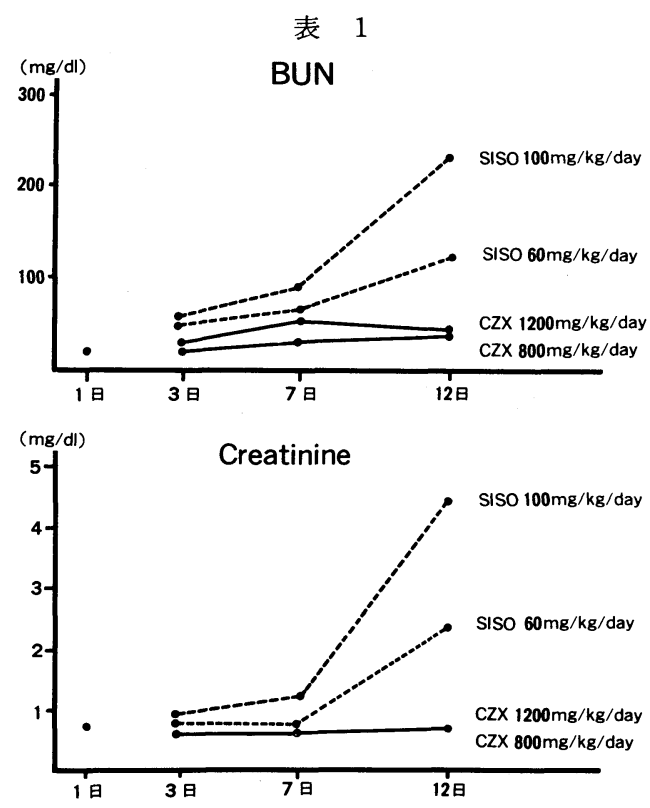

SISO $100 \mathrm{mg} / \mathrm{kg} / \mathrm{day}$ では, 既に上昇している. 投与開 始後 12 日目 (中止後 5 日目) では, SISO 両群とも明ら かな BUN, Creatinine の上昇があり，急性腎不全を若 起している。これに対し, 対照群の CZX $800 \mathrm{mg}$ 打よ び $1,200 \mathrm{mg} / \mathrm{kg} /$ day では, 投与開始後 7 日目, 12 日目 いずれにおいても正常範囲内の数值であった. SISO

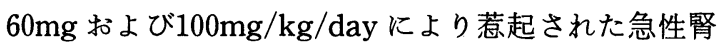
不全は投与開始後 3 週目（中止後 2 週目）で，ほぼ正 常範囲内の数值になり, 投与開始後 4 週目（中止後 3 週目）で，注正常値になった。本実験では対照群も 含めて中止後も死亡例はなかった。

b) 光影所見

腎では, 糸球体にはいずれの時点でも特記する変化 はなく, 变化のみられたのは近位尿細管で, 特に直部 （pars recta）に強かった.

SISO $60 \mathrm{mg}$ 打よび $100 \mathrm{mg} / \mathrm{kg} / \mathrm{day}$ 投与開始 3 日目 では尿細管腔の拡張，刷子縁の乱れが見られる。投与 開始 7 日目では, 上皮細胞の好エオジン性の低下, 腫 大, 空胞変性が出現し, また, 部分的には核の崩壊, 消失がみられ，細胞の極性 (polarity) の喪失もみられ た. 投与開始 12 日目（中止後 5 日目）が变性像がもっ とも強く, 写真 1 のように, 上皮細胞の壊死，尿細管 腔の著明な拡大および内腔内に蛋白円柱, 細胞壊死物 が充満している部位が散見され，いわゆる中毒性急性 尿細管壊死（toxic acute tubular necrosis）に相当す
る像を示した. 回復期の所見としては投与後 3 週（投 与中止後 2 週) では, まだ上皮の変性像が認められる が，円柱は見られず，上皮細胞の好ェオジン性の増加， 上皮細胞の再生への過程が見られた。投与後 4 週（中 止後 3 週) では一部には尿細管腔の拡張, 刷子縁の乱 れなど軽微な変化は見られたが，全体的には，ほぼ正 常に近い像を示した。

対照群の CZX $800 \mathrm{mg}$ 打よび $1,200 \mathrm{mg} / \mathrm{kg} / \mathrm{day} て ゙$ は，投与 12 日目（投与中止後 5 日目）に部分的に尿細 管の拡張, 上皮細胞の好エオシシン性の低下, 空胞変性 が散見される以外ほとんど変性像はみられなかった。 他の日時の光顕所見はほぼ正常であった。

\section{c) 電顕所見}

光学的変化がみられた近位尿細管上皮特に直部 (pars recta)を中心に電䫓的観察を行った。なお SISO $100 \mathrm{mg} / \mathrm{kg} /$ day 群は変性像が激しく, 電顕像の検討に は不適当であったため, SISO $60 \mathrm{mg} / \mathrm{kg} / \mathrm{day}$ 投与群を 中心にして，その所見を記述する。

1）近位尿細管, 特に直部の変化

SISO 投与開始後 3 日目には, 尿細管特に近位尿細 管上皮にミェリン様小体の形成がみられた。 この小体 の初期形成像では尿細管上皮細胞内にある既存の dense body 内に 1 から数個のミェリン様小体が認め られ, 一部にはこれらのミェリン様小体の瘜合像もみ られた（写真 2).これら dense body 内に出現したミ エリン様小体は一層の限界膜に团をれた電子密度の高 い小体で，一見無構造にみえるが，倍率を上げて観察 すると, 約 $30 \sim 50 \AA$ 前後の規則正しい周期性のある明 暗交互の層状構造がみられる。これらの層状構造は部 分的にほぐれて lattice pattern を示したり（写真 3 ）, また，一部には癒合像を認めた（写真 4 ).

一方, 近位尿細管上皮細胞の上部, すなわち, 刷子 縁直下には小型から中等度の apical vesicle, vacuole の増加がみられ, 一部の vacuole 内には小型の不規則 な形のミェリン様構造物がしばしばみられた（写真 5 ).このような像は, SISO の化学成分が尿細管腔か ら apical canaliculi を通って, apical vacuole 内に取 り込まれ，ここに拈いても，ミェリン様小体の形成が 開始されていることを示しているものと考兄られる.

投与日数の経過とともに, 近位尿細管上皮細胞内の ミェリン様小体を含む dense body は数拈よび大きさ を増してくる（写真 6 ). 著しく増大した dense body 内には多数のミェリン様小体を含み, 大きさも大小さ まざまで，それらの癒合像や一部にはdense body内 
で消化されている像もみられる(写真 7$)$ 。このように 増大して多数のミェリン様小体を含む dense bodyの 一部には限界膜が崩壊することにより内部にあったミ エリン様小体は細胞内に放出され単体ないし数個癒合 した形で細胞内にみられるようになる（写真 3 ）。

SISO 投与開始後 12 日目 (中止後 5 日目) が最も強い 変化がみられた。近位および遠位尿細管上皮は腫大し， ミェリン様小体が全体を占める dense body, 数個が癒 合したミェリン様小体, 細胞内の崩壊物を取り込んだ 大型食空胞などが細胞内を占め, 細胞小器官は圧排さ れる傾向を示していた(写真 8 )。これらの変化ととも に，一部の尿細管上皮細胞には崩壊がみられ，多数の 崩壊物とともに多数のミェリン様小体が尿細管腔内に みられた。一部の近位尿細管腔内に扎いて刷子縁に囲 まれている尿細管腔内に多数のミエリン様小体が放出 されて，刷子縁に引っかかっている像もみられ（写真 9)，また遠位尿細管腔内にも多数のミエリン様小体や 細胞の崩壊物の集簇がみられた（写真10).

SISO 投与開始後 3 週目 (中止後 2 週目) 頃では, ミ エリン様小体の消失過程を示してくる，食空胞に取り 込まれたミェリン様小体は強い消化性変化 (lytic change）を受け，さらに経過とともに食空胞は大きさ や数に減少がみられ，電子密度が一段と低くなり，一 部には膜様物質が残存し(写真11), さらに消化が進む と内部の構造が徐々に無構造になっていき，一部では ほほ正常に近いdense bodyに回復し, その内部に膜 様物質の残存がみられる像も存在した（写真12）.

SISO 投与開始後 4 週目（中止後 3 週目）頃になる と，ほぼ修復過程が完成する，すなわち，小さく分割 された食空胞は一見 lysosome 様の構造を示し上皮細 胞基底側へ転送されるか，または，これらの食空胞は 徐々に尿細管腔内に放出されるものと思われる（写真 13).

ミェリン様小体の組織化学的性状の検索として電顕 レベルでの Acid phosphatase 反応は dense bodyの 一部および基質と思われる部位に強い反応産物の沈着 が認められた。ただし，層状構造物は陰性を示した（写 真14).

\section{2）近位尿細管以外の変化}

近位尿細管上皮以外では, 系球体の上皮細胞, 内皮 細胞，メサンギウム細胞，ボーマン襄上皮細胞などに はミェリン様小体の形成はみられなかった。

ミェリン様小体は遠位尿細管および集合管上皮細胞 にもみられるが，近位尿細管のものより小型で電子密
度が高く，低倍率では無構造な dense bodyを思わせ た(写真10)。しかし，高倍率で観察すると密につまっ た層状構造を呈する小体が主体を占めた。

3）腎以外の部のミェリン様小体

ミェリン様小体の出現について腎以外の臟器につい て検討した。腎では尿細管上皮細胞の他に血管の平滑 筋細胞に少数出現した（写真15）が，肝ではごく少数, 肝細胞と kupper 細胞にみられ, 肺, 大動脈の平滑筋に はミェリン様小体の出現はみられなかった。

\section{4）急速凍結置換固定法}

ミェリン様小体について急速凍結置換固定法 ${ }^{11)}$ 行って検討した。市川ら ${ }^{12)}$ は急速凍結置換固定法の像 がより生体に近いと考学ている.

アミノ配糖体投与による dense body 内にみられる 複数のミェリン様小体は肺胞の II 型細胞内にみられ るミェリン様小体のようにスリガラス状の変化ではな く, 通常の化学固定を行ったものと同様の像を示した。 すなわち，電子密度の高い顆粒で，高倍率で観察する と，明瞭な層状構造を示した(写真16). 対照として使 用したコラルジルによるミェリン様小体は一見スリガ ラス状のものとして観察された(写真17)。これは両者 の脂質成分の相違を示している可能性がある.

\section{5）対照群}

対照群の CZX $800 \mathrm{mg}$ 抌よび $1,200 \mathrm{mg} / \mathrm{kg} / \mathrm{day} 7$ 日 間腹腔内注射群では, 光顕でも变化が軽微であったが 電顕上でも大量投与にもかかわらず脂肪变性が散見さ れる以外ほとんど所見はみられなかった（写真18）。

\section{IV. 考 按}

1. アミノ配糖体投与とミェリン様小体の出現 SISO は GM の改良品であり SISO に関する報告は ほとんどみられないので，まず GM に関して文献的考 察を行う。

$\mathrm{GM}$ 投与による腎毒性についての動物実験は短期投 与 ${ }^{13)}$ と長期投与3447714) 16)の報告がある。これらの実験 で, ほぼ共通の組織学的变化として, 変化は主として 近位尿細管にあり，糸球体には変化がないこと，また， それらの変化は投与量ならびに期間に依存しているこ とである．投与量の増加とともに光顕では最初に巣状 壊死が，次に広範囲な壊死が近位尿細管上皮を中心に 生じ，やがて皮質全体に及んでくるとされている。そ の過程で壊死に並行して尿細管上皮が活発に再生し， この再生は投与継続にも拘らず進行するとされてい る.このことは GM の投与がすべての尿細管上皮に一 様に作用しているのでなく，もっとも強く作用を受け 


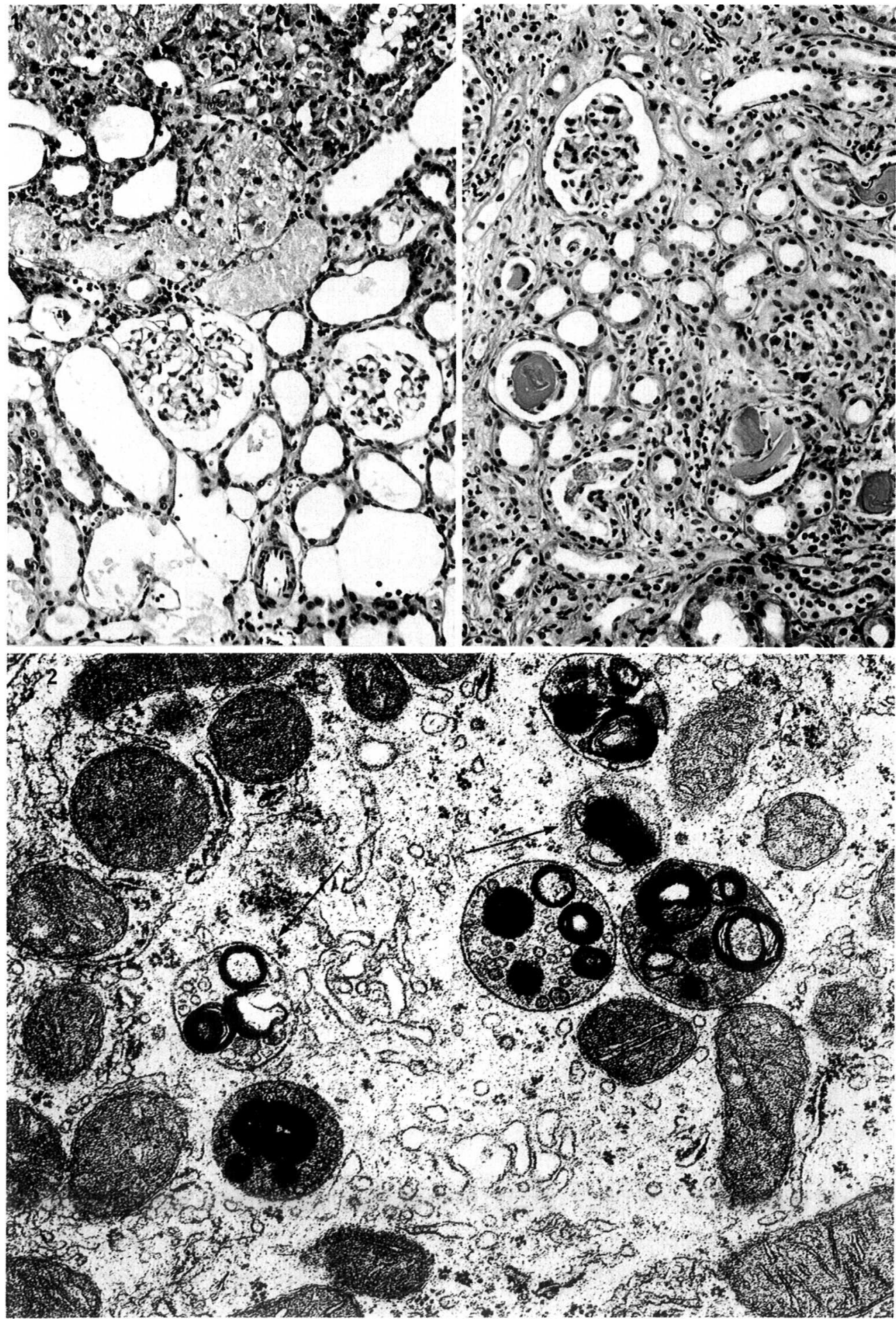




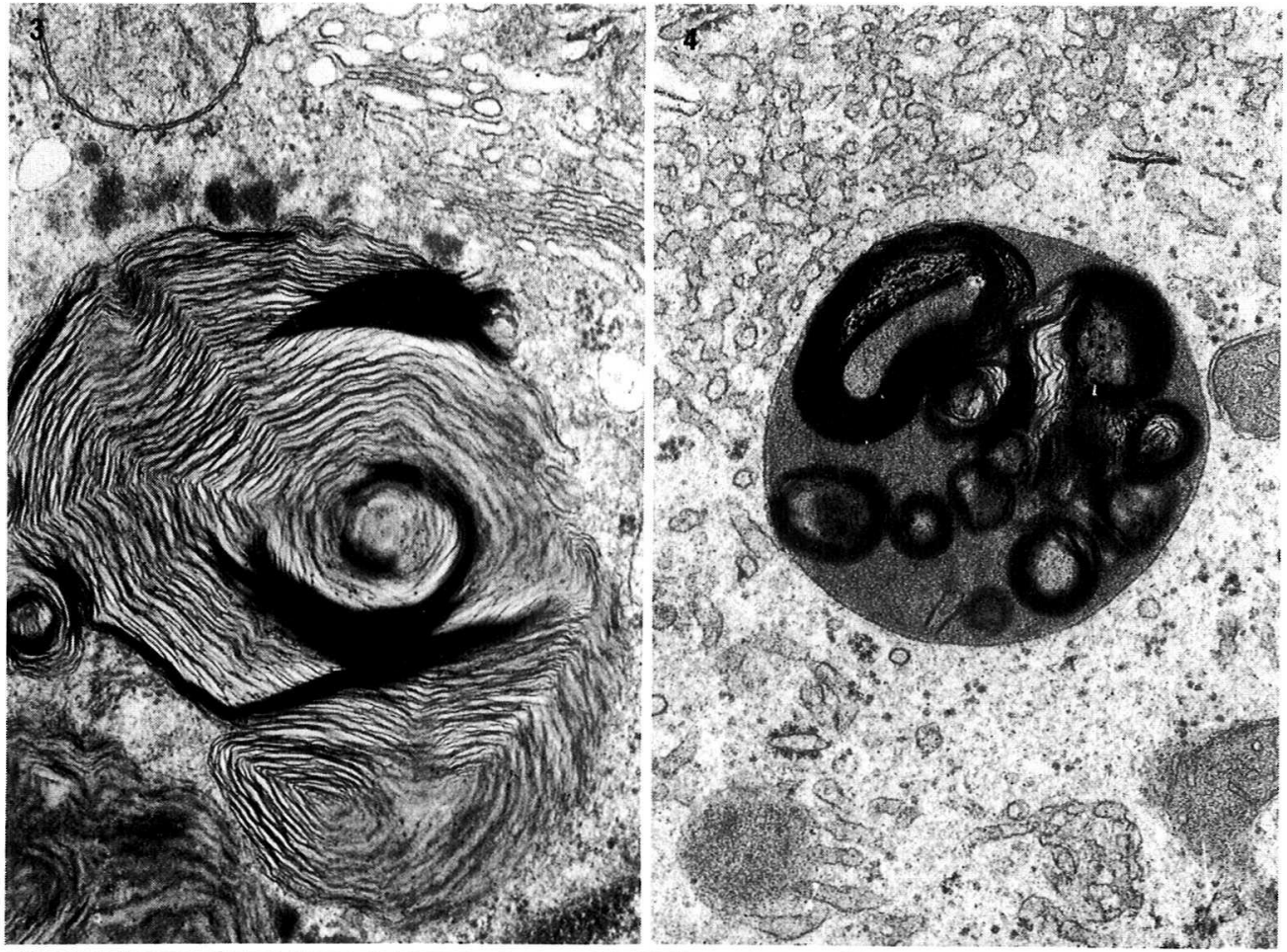

35.

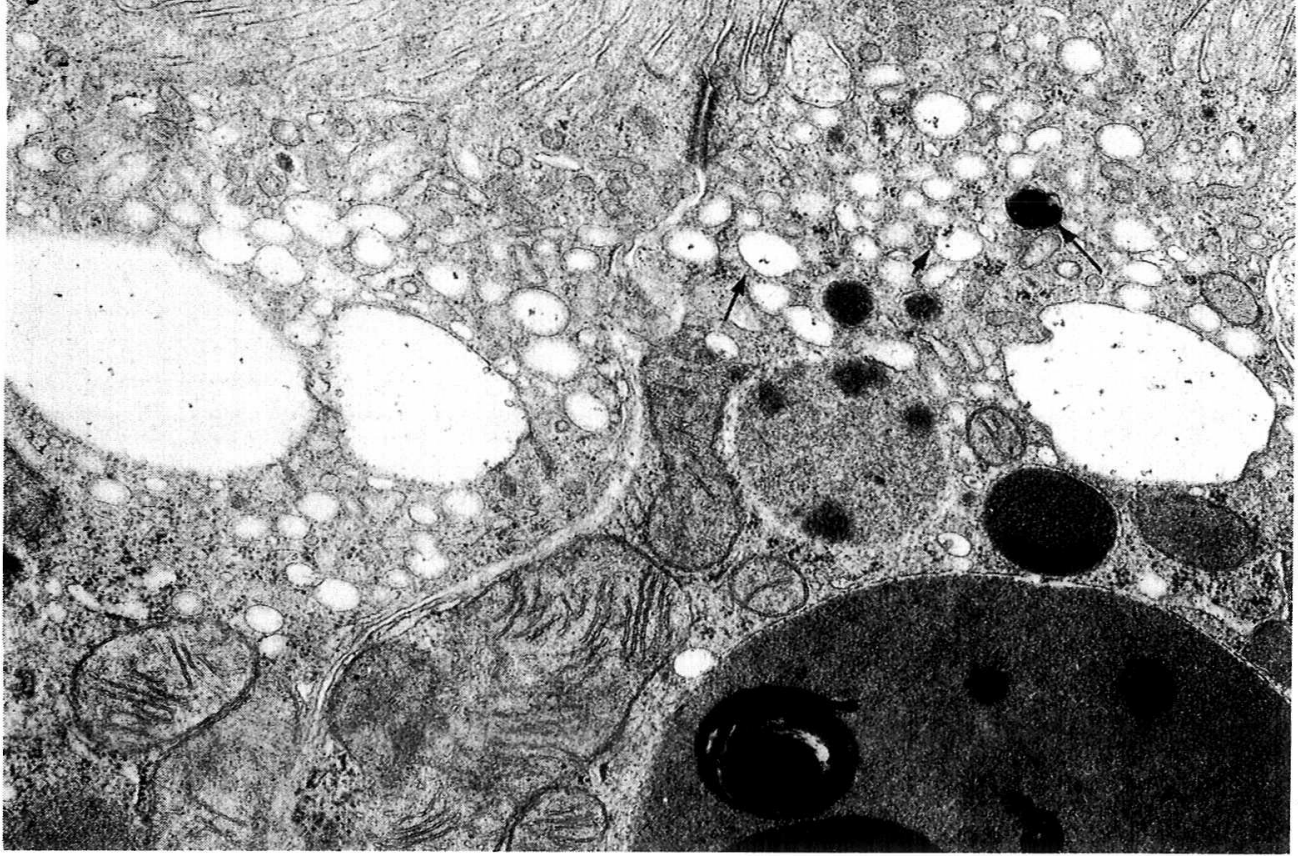



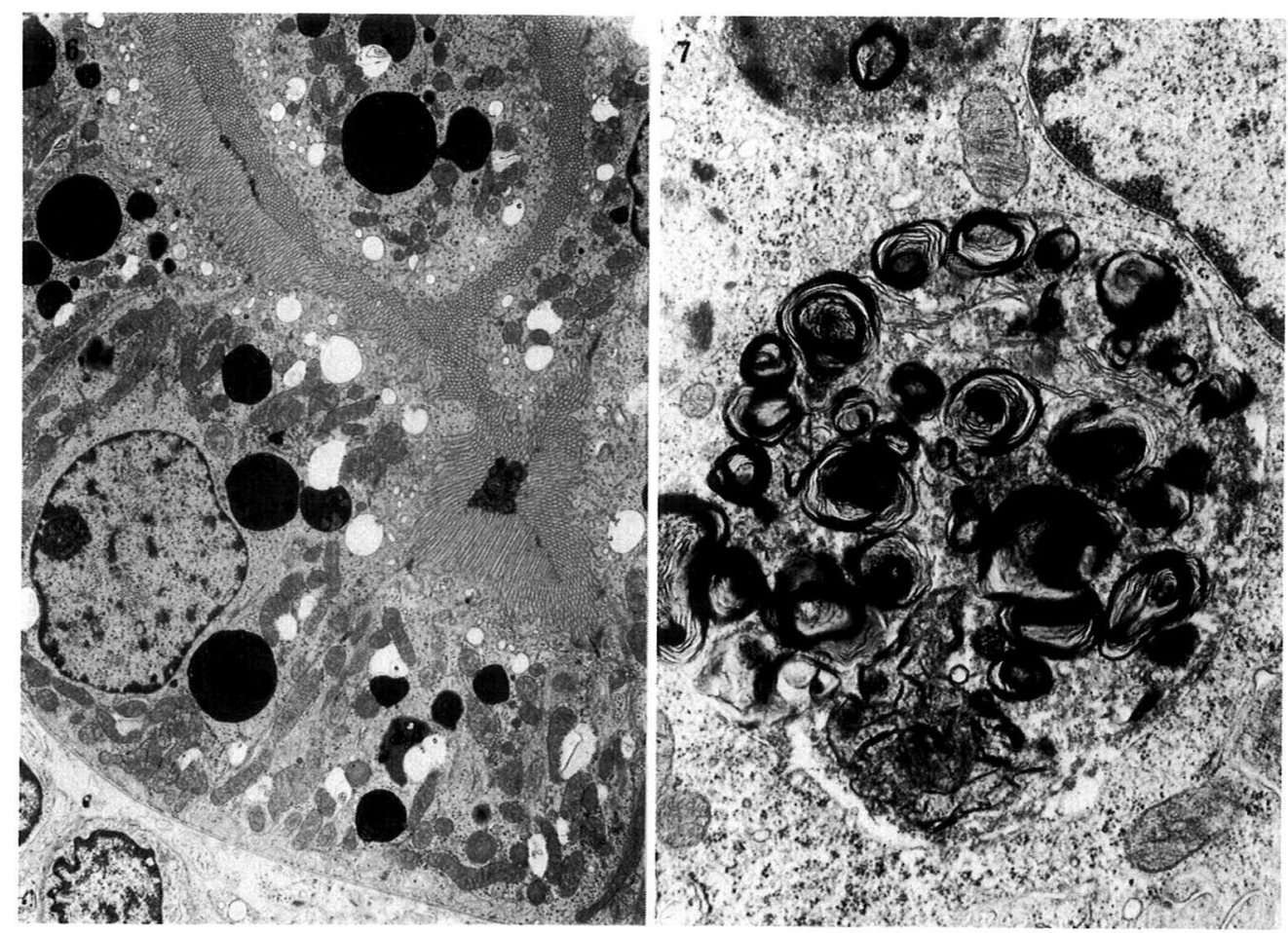

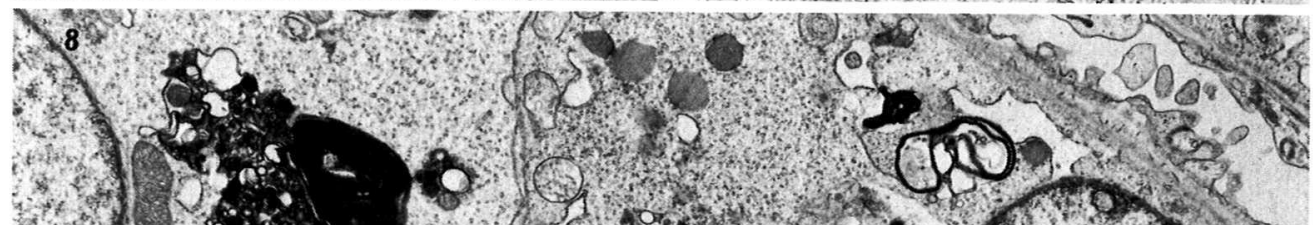

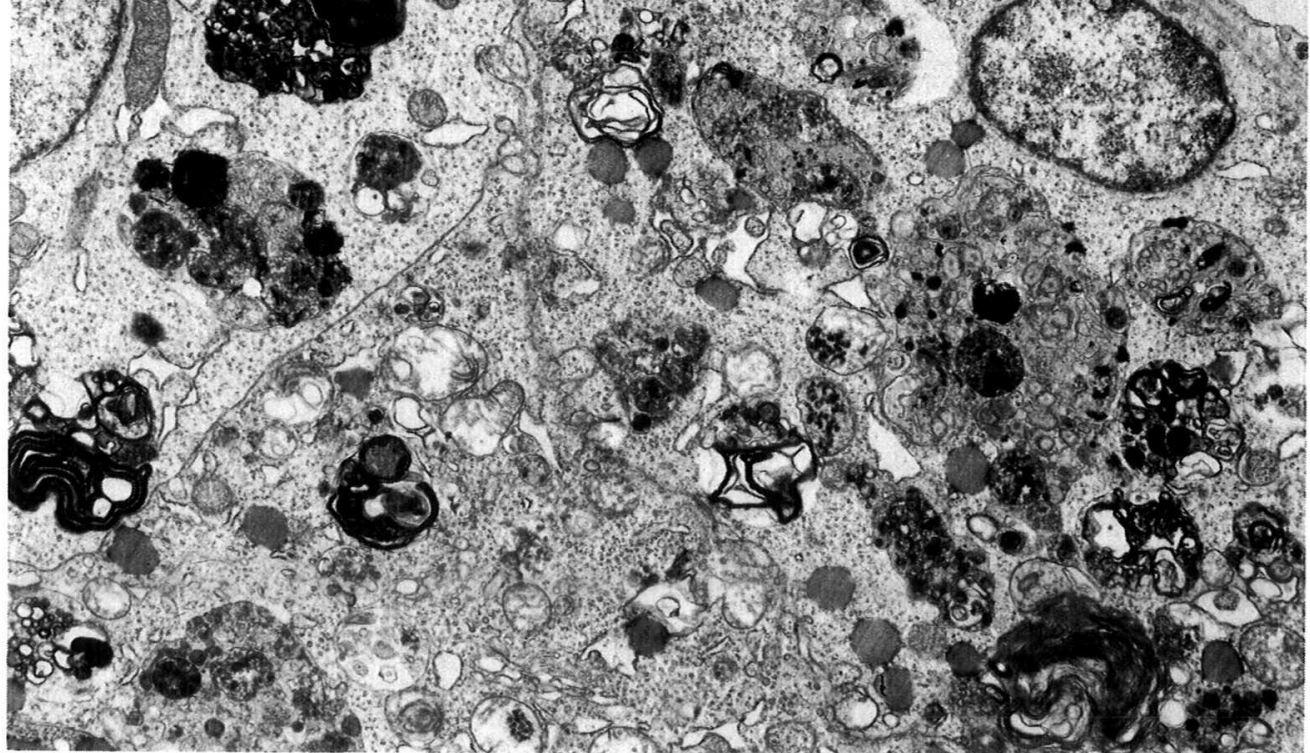



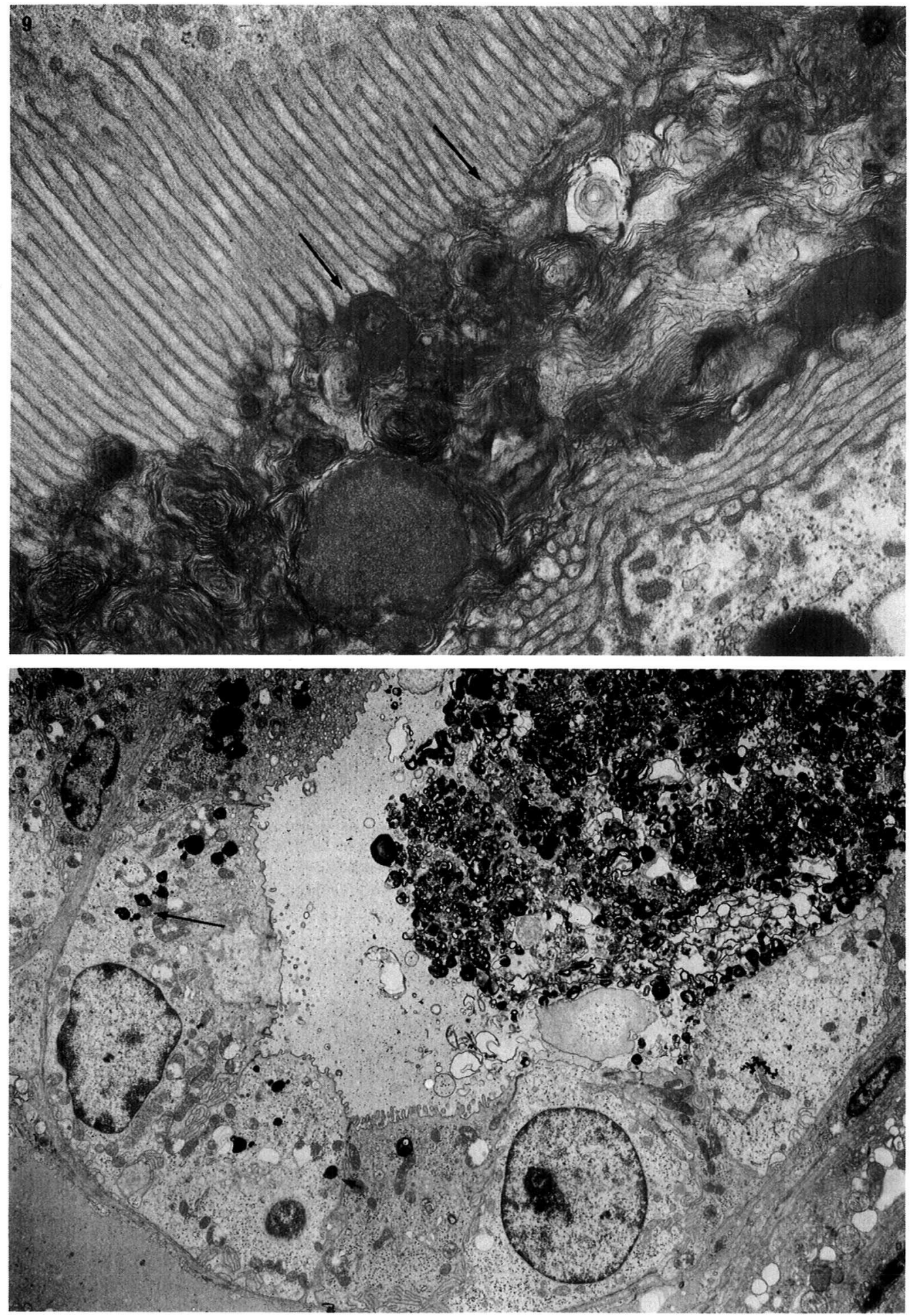


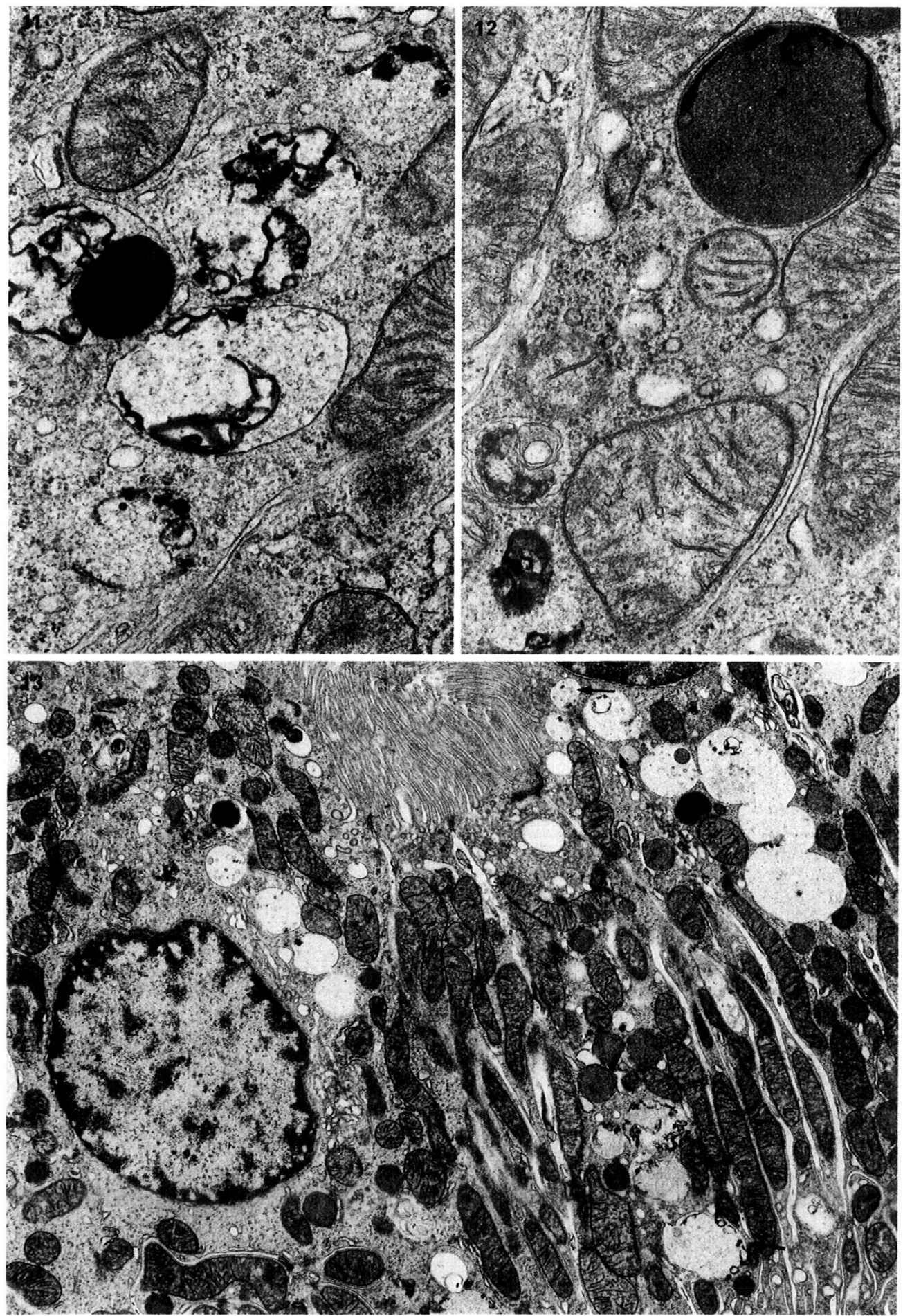




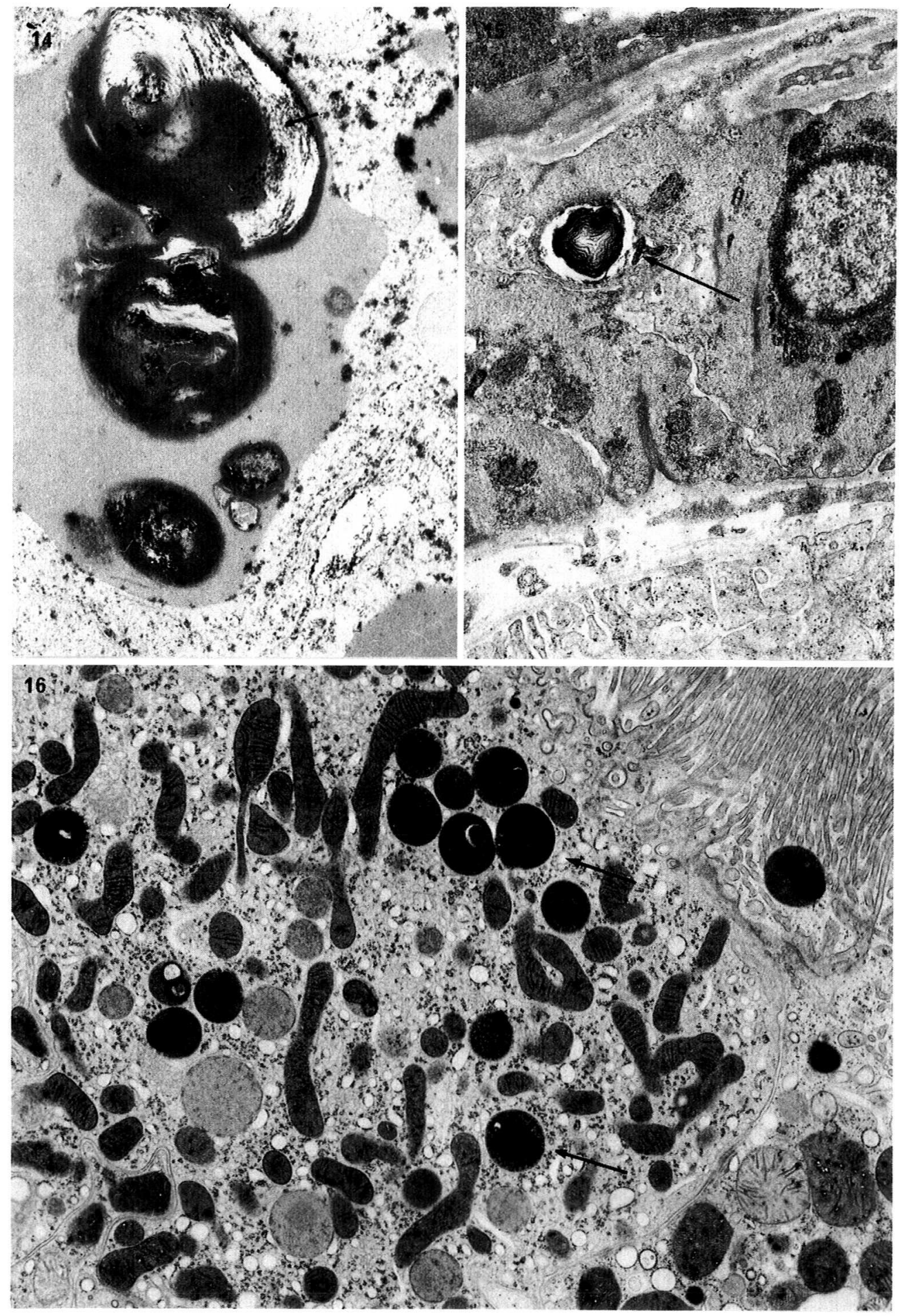



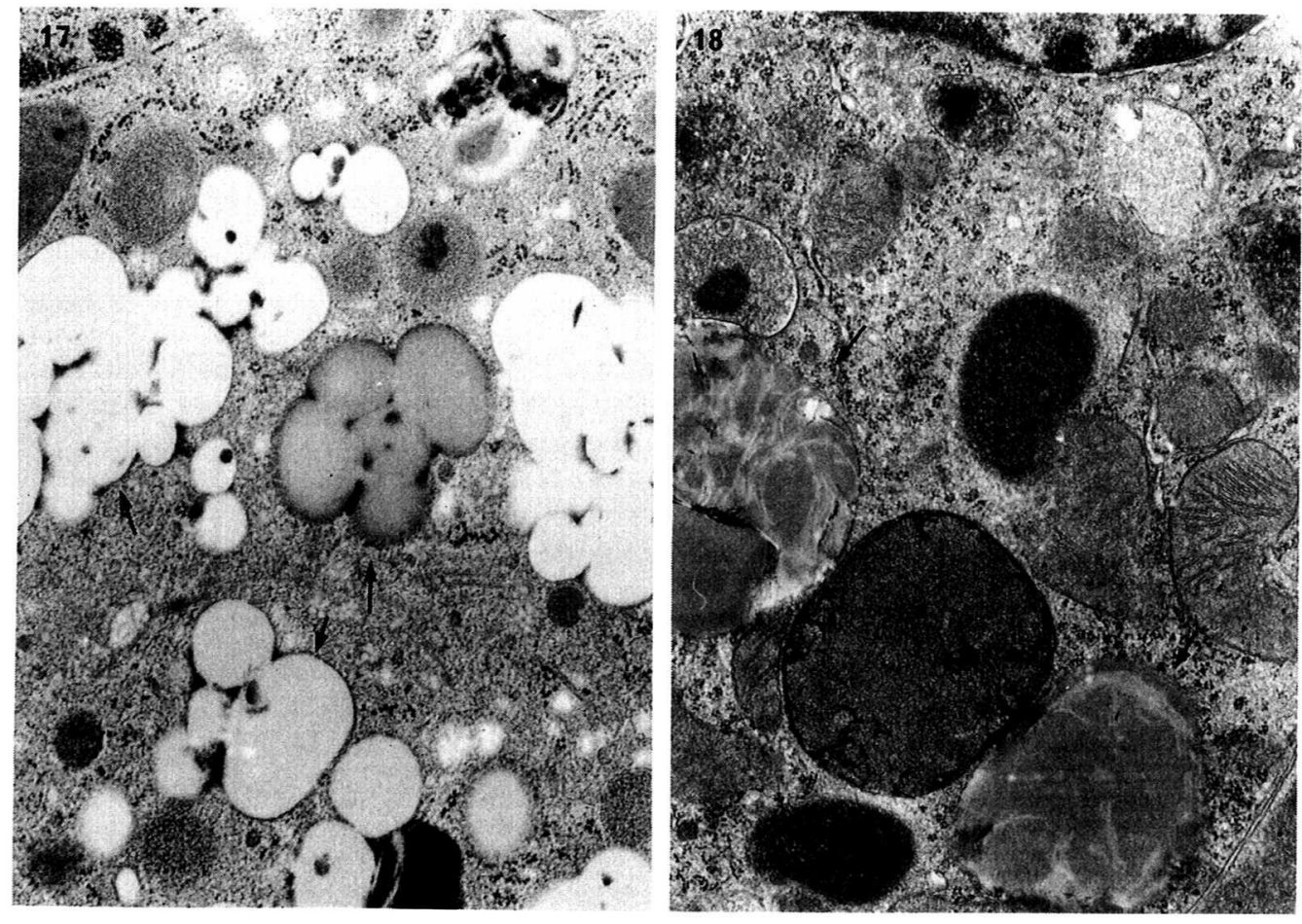

写真説明

実験群はすべて 7 日間のみ連続注射を施行した。

写真 1 SISO $60 \mathrm{mg} / \mathrm{kg} / \mathrm{day}$ 投与 12 日目の光顕像

上皮細胞の広範囲な壊死, 尿細管腔の払大, 内腔内に蛋白円柱, 細胞壊死物が充満している 部位がみらる。

写真 2 SISO $60 \mathrm{mg} / \mathrm{kg} / \mathrm{day}$ 投与 3 日目の近位尿細管上皮の電顕像

ミェリン様小体の形成初期像

dense body 内に 1 から数個のミエリン様小体が認められ, 一部には癒合像もみられる（× 20,000).

写真 3 同上, 投与 7 日目の近位尿細管上皮の電顕像

ミェリン様小体は部分的にほぐれて lattice pattern を示す $(\times 32,000)$.

写真 4 同上, 投与 7 日目の近位尿細管上皮の電顕像

本文説明を参照 $(\times 30,000)$.

写真 5 同上, 投与 3 日目の近位尿細管上皮の電顕像

ミェリン様小体の形成初期像

近位尿細管上皮細胞の刷子縁直下には apical vesicle の増加, 特異空胞の増加がみられ, それ

らの一部にはミェリン様小体の前駆物質もみられた $(\times 20,000)$.

写真 6 同上, 投与 7 日目の近位尿細管上皮の電顕像

ミェリン様小体を含む dense body は数执よび大きさを増してくる $(\times 3,000)$.

写真 7 同上, 投与 7 日目の近位尿細管上皮の電顕像

大小さまざまのミェリン様小体の融合像が dense body 内にみられ, dense body の膜の崩壊

もみられる $(\times 15,000)$.

写真 8 同上, 投与 12 日目の近位尿細管上皮の電顕像

ミェリン様小体の融合したもの, 大型食空胞などが細胞内を占め, 細胞小器官などの圧排像 を示す $(\times 6,000)$.

写真 9 同上, 投与12日目の近位尿細管上皮の電顕像

近位尿細管上皮細胞の刷子縁に囲まれた尿細管腔には放出された多数のミェリン様小体がみ

られた $(\times 21,000)$. 
写真10 同上，投与12日目の遠位尿細管上皮の電䫒像

遠位尿細管腔にも多数のミェリン様小体や細胞崩壊物の集簇がみられた。矢印のように，融 合傾向の少ない, 小型のミェリン様小体がみられた $(\times 3,000)$ 。

写真11 同上, 投与 3 週目の近位尿細管上皮の電顕像

消化性変化をうけた食空胞で，一部に高電子密度の膜様物質の残存がみられる $(\times 24,000)$. 写真 12 同上, 投与 3 週目の近位尿細管上皮の電顕像

ほぼ正常に近い大きさの dense bodyに回復してきているが, 一部に膜様物質が存在してい る $(\times 24,000)$.

写真 13 同上, 投与 4 週目の近位尿細管上皮の電顕像

食空胞は基底側において intra lysosomal digestion をらけるか，または一部は尿細管腔内へ 放出される $(\times 6,000)$ 。

写真14 同上, 投与 7 日目の電顕組織化学 (Acid phosphatase)

矢印は基質に一致して鉛の強い沈着を示す。ミェリン様小体は ACP 陽性であり, lasosome の性状を有する $(\times 24,000)$.

写真 15 同上, 投与 7 日目の腎臓の血管の平滑筋の電顕像

腎の血管の平滑筋細胞にミェリン様小体が出現した $(\times 15,000)$.

写真 16 同上, 投与 7 日目の近位尿細管上皮の電顕像, 急速凍結置換固定法

矢印のよらにミエリン様小体は通常の化学固定と同様な像であった $(\times 9,000)$.

写真17 コラルジル投与の電顕像, 急速凍結置換固定法

矢印のよらにコラルジルによるミエリン様小体は層状構造がみられず，均一でスリガラス状

の内容を示すピッド顆粒として認められる $(\times 20,000)$.

写真 $18 \mathrm{CZX} 800 \mathrm{mg} / \mathrm{kg} / \mathrm{day}$ 投与 12 日目の近位尿細管上皮の電顕像

脂肪変性が散見される以外変化はみられなかった. 矢印は脂肪変性を示す $(\times 15,000)$.

た細胞は急速に壊死を起こし，GMによる傷害をより 受け難い抵抗力を持つ若い細胞と执きかわっているの であろらと推測されている。しかし，アミノ配糖体投 与の動物実験および人体例 ${ }^{17118)}$ で共通して指摘される ことは，投与初期から，電顕上，主に近位尿細管上皮 に出現するミェリン様小体であり投与量の増加ととも に尿細管上皮細胞全体を占めるほどに増加するとされ ている。

GM の腎毒性に関する動物実験はヒトに用いる量の 10倍から40倍の高用量を用いたものがほとんどであ $3^{4) 13) 15)}$ が，治療範囲内の用量 (1 5mg/kg/day)を使 用した実験では, Kosek ら $\left.{ }^{14}\right)$ はわずか $1 \mathrm{mg} / \mathrm{kg} / \mathrm{day}$ 1 回投与48時間後の電顕像で, すでにラットの近位尿 細管上皮にミェリン様小体を生じたと述べている。ま た, Baylis ら ${ }^{7)}$ の実験では $4 \mathrm{mg} / \mathrm{kg} / \mathrm{day}$ の GM 投与で ラットに同様のミェリン様小体の出現拉よび糸球体濾 過値 (GFR) の $48 \%$ の減少を認めている。これらの投 与量では，当然，腎機能異常は起こらず，その時点で ミェリン様小体が出現していることはミェリン様小体 の出現は単なる GM 投与の指標にしか過ざず, 腎毒性 とは無関係ではないかとの理論の根拠になっている。

GM 起因性のヒトの急性腎不全は投薬を中止すれ ば, ほとんどの場合，回復するとされている。Hought- on ら ${ }^{17)}$ は腎切除および腎生検を施行した109例中19例 に近位尿細管上皮にミェリン様小体が存在し，その19 例中15例が $\mathrm{GM}$ の投与を受けた患者で，そのらち 1 例 のみが腎不全の臨床症状を示したと報告している。

すべてのアミノ配糖体投与により共通して生ずる特 徵的な電顕レベルの変化はミェリン様小体の出現であ り, これ以外の変化は非特異的なものとされている。

2. ミェリン様小体の形成と消失

SISO 投与群ではアミノ配糖体投与に共通して電顕 上ミェリン様小体がみられたが。この形成，消失過程 に関する報告は少ない。

今回の検索からミェリン様小体は写真 2 のように。 上皮細胞内にある dense body 内に 1 から数個のミエ リン様小体がみられた。このことは, dense bodyすな わち lysosome そのものでミエリン様小体が形成され ていて, lysosome が形成過程の中心と考兄られる。電 顕組織化学 (Acid phosphatase) でも, 写真14のよう にミエリン様小体の基質に一致して鉛の強い沈着がみ られ，ミェリン様小体は lysosome の性状を有してい ることが判明した。

また一方, 写真 5 のように, 刷子縁直下に pinocytotic vesicle の増加, 大小の拡張した空胞がみ られ，その中にミェリン様構造物が癒合し，より大き 
なミエリン様小体の形成へと移行する像がみられた。 これは，技そらく，SISOの化学成分が尿細管腔から pinocytosis の形式で, apical canaliculi 通って apical vacuole 内に取り込をれ，その過程で膜脂質成 分である燐脂質と結びついて，ミェリン様小体を形成 してくるものと考兄られる。つまり， ミェリン様小体 の形成過程は lysosome そのものでの形成を主とし， それとは別に pinocytosis が関与したものと 2 通りあ るように思われた。

ミェリン様小体の消失過程については, 換言すれば, 近位尿細管上皮の修復過程でもあるが，食空胞内に蓄 積されたミェリン様小体は写真11のように徐々に lysosome 内の酸性水解酵素による消化性変化 (lytic change）を受けるようである。はじめは無構造な電子 密度の高い物質となり，これが大きさ，数ともに減少 しつつ, 電子密度も次第に低くなり小さく分割されて いく，写真13のように，小空胞は主に上皮細胞基底部 に転送され，最後に主として lysosomeにより処理さ れ，一部は尿細管腔内へ排出されると考只られる.

3. 燐脂質蓄積症について

薬剤投与により出現するミェリン様小体は病理学的 には薬剂起因性燐脂質蓄積症, drug-induced phospholipidosis ${ }^{19) ~ 22) ~}$ と解釈される。従ってアミノ配 糖体投与による本実験も実験的燐脂質蓄積症の一つと 考えられる。

薬剂起因性燐脂質蓄積症（ミェリン様小体の形成） そついては, すでに, Lüllmann ら ${ }^{20221)}$ が詳細な報告を しているので, 本実験と比較検討してみたい.

表 2 , 表 3 は Lüllmann らの原図を参考にして判り やすく書いた表であり, 表 2 のようにミェリン様小体 を形成する薬剤は数十種類にも及んで拈り,なかでも 代表的なものは燐脂質脂肪肝を起こす Anti anginal drug としての 4,4'-diethylaminoethoxy hexestrol ( ラルジル）拈よび網膜症を起こす Antimalarial drug としての chloroquineである。これらの薬剤は Amphiphilic 或いは Cationic amphiphilic drug という言 葉で一括されており ${ }^{20221)}$ ，これらの薬剤には燐脂質と 反応する 2,3 の共通した化学的性質が認められる. (1) いずれの薬剤も塩基性であり, 塩基性 amine グ ループに属している. (2) 同一分子中に親水基と蹯水基 の両者の性質を有している.(3) 1 ないし数個の芳香環 を有している。 以上 3 項目が共通した化学的性質と考 えられる。しかし、アミノ配糖体では(1)の塩基性 amine グループであることは同じであるが(2)，(3)は親

\section{表 2 燐脂質蓄積症炭起薬剂}

Amphiphilic drugs

1) Antianginal drug 4.4' - diethylaminoethoxyhexestrol Aminodarone Perhexiline

2) Antidepressant drug Imipramine Clomipramine Iprindole 1-Chloro-amitriptyline Zimelidine Amitriptyline Noxiptiline
3) Antimalarial drug Chloroquine Mepacrine

4) Antihistaminc drug Chlorcyclizine Chlorphentermine Fenfluramine

6) Hypocholesterolemic drug Triparanol Azacosterol

7) Neuroleptic drug Clozapine Chlorpromazine

8) Psychotrophic drug Lysergic acid
5) Anorectic drug

表 3 Amphiphilic 薬剤の Lysosome 内蓄積および 複合脂質との結合

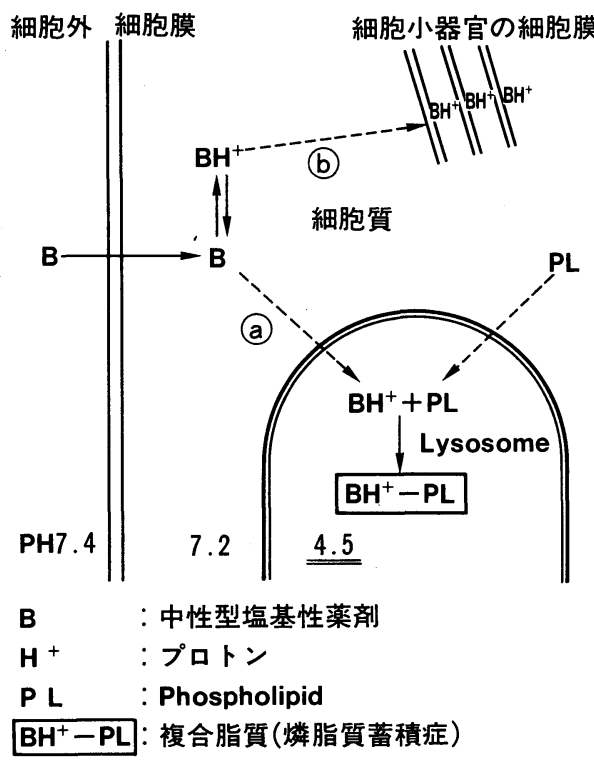

水基が主であり, 芳香環はなく, Amphiphilic 薬剤とは 別のグループであると思われる，ただ，両薬剤とも， ミェリン様小体の形成はいずれも可逆性であり，投与 中止とともに細胞は回復に向から性質を有するなど類 似した点も認められる。

燐脂質蓄積の発生機序について, Lüllmann らは, 表 3 のように Amphiphilic 薬剤である中性型塩基性薬 剂（B）は固有の疎水性の性質のため, 膜透過性が非 常に高く, 容易に細胞膜や lysosome 膜を通過し得る. その後, プロトン $\left(\mathrm{H}^{+}\right)$に出会い, 特に lysosome 内 では高濃度の $\mathrm{H}^{+}$に出会い, 直ちに, プロトン付加型塩 基性薬剤 $\left(\mathrm{BH}^{+}\right)$となり，これは逆に膜透過性が著し く低下するため, 一度, 細胞質内や lysosome 内へ透過 
した $\mathrm{BH}^{+}$はそれらの内部に蓄積しやすくなってくる。 ここで問題とされるのは, pH の差であり, lysosome 内の $\mathrm{pH}=4.5$ であり, 細胞質の $\mathrm{pH}=7.2$ と比較して極 端に差があるため細胞質に比し, 約 1,000 倍に近い付加 速度でBが lysosome 膜を透過して, lysosome 内に取 り込まれ，表 3 において，大部分が@のコースを通っ て lysosome 内に蓄積され，ごく少量がbのコースで 細胞小器官内に蓄積されるものと考えられる. lysosome 内一蓄積された $\mathrm{BH}^{+}$は, 主に lysosome 膜 および細胞小器官などの膜脂質成分である燐脂質 (PL) と結びついて複合脂質 $\left(\mathrm{BH}^{+}-\mathrm{PL}\right)$ を形成し, 既存の lysosome 内の phospholipase によって，それ 以上分解されることが不可能となり薬剤一燐脂質複合 体の型で蓄積され，燐脂質蓄積症となり，その時点で， ミェリン様小体として電顕的に可視化されるのでない かとされている.そして, $\mathrm{BH}^{+}-\mathrm{PL}$ は理論的には可逆 性であるが投与量の増加とともに，何らかの不可逆的 な secondary degeneration が惹起されるのではない かとされている.

Lüllmann らは, ミェリン様小体の形成の主座は, 以 上のように，あくまで lysosome 内が中心であるとし ている.

本実験でもアミノ配糖体のミェリン様小体の形成は lysosome が中心と考学るが, その形成機序について生 化学的な明確な考方方がない現在, Lüllmann らの, こ のよらな考光方は十分，参考にすべきであろうと思わ れる。

Amphiphilic 薬剂投与の動物実験で全身諸藏器の電 顕上の観察が報告されているのはコラルジルだけであ り,コラルジル投与ではラットの全身諸藏器にミェリ ン様小体の出現がみられた ${ }^{19)}$. しかし, 本実験では, ア ミノ配糖体投与によるミェリン様小体は腎尿細管上皮 にのみみられ，他臓器では，ほとんど出現しないと云 ら臓器特異性があることが判明した。この事実と腎毒 性と何らかの関連性があると思われる。また，急速凍 結置換固定法では写真16，17のようにコラルジル投与 とアミノ配糖体投与によるミェリン様小体は両者の間 に明らかに差があり，ミェリン様小体を形成する燐脂 質成分の差異ではないかと考兄られる，以上のように アミノ配糖体投与によるミェリン様小体の本態は不明 な点が多く今後, 更に形態学的, 薬理学的検討が必要 であろうと思われる。

4.アミノ配糖体投与と腎毒性

アミノ配糖体投与による急性腎不全は投与量依存性
であり, 多尿, 低浸透圧尿, 糸球体濾過値 (GFR) の 減少を伴った nonoliguric な急性腎不全であるとされ ている377)14)16)23)24)。また動物実験では GM を投与寸る とラットの腎では, その85\%が皮質に集中し ${ }^{25)}$,オート ラジオグラフィーの研究により，GM 投与の大部分は 近位尿細管上皮細胞内へ取り込まれ, lysosome 内に蓄 積されるとされている26).

以上のように，アミノ配糖体は，ほとんどが近位尿 細管上皮細胞の lysosome 内に蓄積されるものと考兄 られる。本実験でも電顕所見から SISO一燐脂質複合 脂質であるミェリン様小体は lysosome がその形成の 中心であると考觉られる。

ミェリン様小体の形成機序について, Kosek ら ${ }^{14)}$ $\mathrm{GM}$ 投与によるミェリン様小体について, 細胞内外の 膜脂質成分の燐脂質が $\mathrm{GM}$ と結びついた lysosome 内 消化の産物であろうとしており，注ぼ大筋においては 前述した Lüllmann $5^{20121)}$ の説と同様である。また， $\mathrm{JaO} 5^{271}$ は $\mathrm{GM}$ 投与によるミェリン様小体は薬剤投 与による上皮細胞の恒常性を保護しようとする生体の 防御反応であり, この作用が限界を越光た時, 細胞内 機能異常がおこり，不可逆的なダメージを受けるので はないかと考按している。

我々も，これらの考光方とほぼ同様であり，SISO の 化学成分が主に lysosome 内で, 膜脂質成分の燐脂質 と結びついてミェリン様小体を形成し，投与量の増加 とともに, 脂質代謝に関与する酵素活性の低下も起こ り, ミェリン様小体の過度の形成で上皮細胞の機能異 常を起こしてくるものと考学られ，いわゆる lysosome over loading の問題が起こってくると考えられる.し かし，ミェリン様小体の過度の形成だけで尿細管壊死 が起こるとは考完難い。つまり, 百瀬 ${ }^{28)}$ がすでに報告し ているように, lysosome 酵素の放出による上皮細胞の 自家融解的過程を考支ないと尿細管壊死，腎毒性の問 題は解決しない。

この点を電顕所見から考察していくと, 前述したよ 5 に, 写真 5 で示すょらにSISOの化学成分が pinocytosis の形式で取り込をれ apical vacuole 心にして，単体または融合した形でミェリン様小体を 形成し，投与量とともに，その数も増加していく，ま た, 一方, 写真 2 のらにdense bodyすなわち lysosome そのものであるが, その内でミェリン様小体 が形成され，投与量の増加とともに, dense body 内で ミェリン様小体の過形成が括こり, 写真 7 のように, しばしば dense body の限界膜が破れて, ミェリン様 
小体が細胞内へ放出されるすのと思われる。これらは 写真14で示すように lysosome 酵素の性状，つまり酸 性水解酵素を有している. そして変性像の極期では写 真 8 のように,さむざまの形のミェリン様小体やその 融合像や大型の食空胞がみられ，上皮細胞内の細胞小 器官の圧排像がみられるが興味深いことは，どの上皮 細胞においても細胞内小器官の圧排像までであり細胞 崩壊像はみられなかった。それにもかかわらず，写真 9, 写真10のように尿細管腔内にはミェリン様小体を 主とする細胞崩壊物がみられた。この事実は lysosome 酵素の放出による上皮細胞の自家融解作用による細胞 崩壊の過程があると考学ざるを得ない。つまり, dense body の崩壊によりミェリン様小体が細胞内へ放出さ れるとともに lysosome の酵素の放出も起こり, 一部 の細胞では自家融解作用が始まってくるものと考兄ら れる。

結局，アミノ配糖体投与による腎毒性の出現は形態 学的には尿細管壊死の形式で出現するが, それには薬 剤投与量の増加によるミェリン様小体の過形成と lysosome overloading の問題, さらに, lysosome 酵 素が上皮細胞内に放出され上皮細胞の自家融解作用を 起こしてくると云ら二つの面から考劣るのが適当であ ると思われる。

\section{V. 結 語}

SISO 投与により惹起されるラットの腎におけるミ エリン様小体の形成過程, 推移, 消失過程捛よび腎機 能との関係, 薬剤起因性燐脂質蓄積症について考察し た.

1）CZX $800 \mathrm{mg}$ および $1,200 \mathrm{mg} / \mathrm{kg} /$ day 7 日間腹 腔内注射では腎機能は正常であったが SISO $60 \mathrm{mg}$ お よび $100 \mathrm{mg} / \mathrm{kg} / \mathrm{day} 7$ 日間筋注では急性腎不全が起 きた。

2) ミェリン様小体は電顥組織化学 (Acid phosphatase）にて lysosome の性状を有することが判明し た。また：ミェリン様小体は電顕上，腎以外では肝で ごく少数みられたほか, 肺, 大動脈の平滑筋ではみら れなかった。

3）ミェリン様小体は，アミノ配糖体の化学成分が pinocytosis の形式で刷子縁から取り込をれ, apical vacuole 内で形成されるものと lysosome 内部で形成 されるものと二通りの形成過程が考えられ, 主に lysosome 内部で形成されるものと思われる.

4）ミェリン様小体の消失過程には, (1) ミェリン様 小体の細胞内消化, 分解, いわゆる intra lysosomal digestion, (2) 食空胞となり, 尿細管腔内へ放出, (3) ミ エリン様小体の尿細管上皮細胞における細胞充填によ る腫大, 崩壊の 3 つの機序が考えられる.

5） SISO 投与による尿細管障害は，投与量増加とと もに主に lysosome 内を中心にしてミェリン様小体の 過形成が起こり, lysosome overloading の問題が起こ り, 細胞内恒常性が失われ, また, lysosome 膜は崩壊 して lysosome 酵素を上皮細胞内へ放出, 細胞の自家 融解作用を起こしてきて，尿細管壊死を若起するもの と思われる。

6) Amphiphilic 薬剤であるコラルジル投与による ミェリン様小体は全身諸臓器に出現するのに対し, ア ミノ配糖体のそれは主に腎の尿細管上皮に出現し, 臓 器特異性があり, この点之腎毒性との関係は今後, さ らに検討の必要がある。

以上のょうに，アミノ配糖体投与の腎毒性の作用機 序に関しては, まだ, 不明の点が多いが今後は生化学 および薬理学的研究を併せ行い, 機能と形態の両面か らの検討が必要であると考えられる。

稿を終るに臨み, 本論文の御校閲を賜りました慶応大学 医学部病理学教室坂口弘教授に心から感謝の意を表しま す. また終始技術的御援助を頂いた同病理学教室榎本康弘 先生に感謝致します。

本論文の要旨は第14回日本臨床電子顕微鏡学会, 第71回 日本泌尿器科学会総会に於いて報告した。

\section{文献}

1) Houghton, D.C., Hartnett, M., CampbellBoswell, M., Porter, G.A. and Bennett, W.M. : A Light and electron microscopic analysis of gentamicin nephrotoxicity in rats. Am. J. Pathol., 82, 589-599, 1976.

2) Bennett, W.M., Plamp, C.E., Parker, R.A., Gilbert, D.N., Houghton, D.C. and Porter, G.A.; Renal transport of organic acids and bases in aminoglycoside nephrotoxicity. Antimicrob. Agents Chemother., 1979, in press.

3) Cohen, L., Lapkin, R. and Kaloynides, G.J.: Effect of gentamicin on renal fynction in the rat. J. pharmacol. Exp. Ther., 193, 264-273, 1975.

4) Cuppage, F.E., Setter, K., Sullivan, L.P., Reitzes, E.J. and Melnykovych, A.O.: Gentamicin nephrotoxicity. Virchows Arch. [Cell Pathol.] 24, 121-138, 1977.

5) Kluwe, W.M. and Hook, J.B.: Functional nephrotoxicity of gentamicin in the rat. Toxicol. Appl. Pharmacol., 45, 163-175, 1978. 
6) Lapkin, R., Bowman, R. and Kaloyanides, G.J. : Effect of gentamicin of p-aminohippurate metabolism and transport in rat kidney slices. J. Pharmacol. Exp. Ther., 201, 233-242, 1977.

7) Baylis C., Rennke, H.R. and Brenner, B.M.: Mechanisms of the defect in glomerular ultrafilation associated with gentamicin administration. Kidney Int., 12, 344-353, 1977.

8）シセプチン文献集：Chemotherapy 特集号, 26, Supplement, p. 1, 1978.

9）木村茂三：低分子デキストランによる浸透圧性腎 症の臨床病理学的研究. 日腎会誌, 11, 605-627, 1969.

10）木村茂三：低分子デキストランによる漫透圧性腎 症回復期の病理学的研究. 日腎会誌, 12, 669-681, 1970.

11）市川 厚：急速凍結置換法, 電子顕微鏡， $16 ， 47$, 1981.

12）市川 厚，池田大忠：日本電子顕微鏡学会第36回 学術講演会予稿集, p. 30, 1980.

13) Vera-Roman, J., Krishnakantha, T.P. and Cuppage, F.E.: Gentamicin nephrotoxicity in rats. Lab. invest., 33, 412-417, 1975.

14) Kosek, J.C., Mazze, R.I. and Cousins, M.J.: Nephrotoxicity of gentamicin. Lab. Invest., 30 , 48-57, 1974.

15) Gilbert, D.N., Houghton, D.C., Bennett, W.M., Plamp, C.E., Reger, K. and Porter, G.A.: Reversibility of gentamicin nephrotoxicity in rats : Recovery during continuous drug administration. Proc. Soc. Exp. Biol. Med., 160, 99-103, 1979.

16) Gilbert, D.N., Plamp, C.E., Starr, P., Bennett, W.M., Houghton, D.C. and Porter, G.A.: Comparative nephrotoxicity of gentamicin and tobramycin in rats. Antimicrob. Agents Chemother., 13, 34-40, 1978.

17) Houghton, D.C., Campbell-Boswell, M.V., Bennett, W.M., Porter, G.A. and Brocks, R.E. : Myeloid bodies in the renal tubules of humans: Relationship to gentamicin therapy. Clin. Nephrol., 10 : 140-145, 1978.
18) Bennett, W.M., Gilbert, D.N., Houghton, D.C. and Porter, G.A.: Gentamicin nephrotoxicitymorphologic and Pharmacologic features. West. J. Med., 126, 65-68, 1977.

19）渡辺陽之輔, 田代征夫：DH (4-4'-diethylaminoethoxy hexestrol)投与による脂質蓄積症 の形態学一実験的研究を中心として一. 慶応医学, 51, 151-164, 1974.

20) Lüllmann, H., Lüllmann-Rauch, R. and Wasserman, O.: Drug induced phospholipidosis. CRC Crit. Rev. Toxicol., 4, 185-218, 1975.

21) Lüllmann, H., Lüllmann-Rauch, R. and Wasserman, O.: Lipidosis induced by amphiphilic cationic drugs. Biochem. Pharmacol., 27, 1103-1108, 1978.

22) Aubert-Tulkens, G., Van Hoof, F. and Tulkens, P.: Gentamicin-induced lysosomal phospholipidosis in cultured rat fibroblasts : Quantitative ultrastructural and biochemical study. Lab. Invest., 40, 481-491, 1979.

23) Luft, F.C., Patel, V., Yum, M.N., Patel, B. and Kleit, S.A.: Experimental aminoglycoside nephrotoxicity. L. Lab. Clin.Med., 86, 213-220, 1975.

24) Luft, F.C., Bloch, R., Sloan, R.S., Yum, M.N., Costello, R. and Maxwell, D.R.: Comparative nephrotoxicity of aminoglycoside antibiotics. J. Infect. Dis., 138, 541-545, 1978.

25) Luft, F.C. and Kleit, S.A. : Renal parenchymal accumuulation of aminoglycoside antibiotics in rats. J. Infect. Dis., 130, 656-659, 1974.

26) Silverblatt, F.J. and Kuehn, D. : Autoradiography of gentamicin uptake by the rat proximal tubule cell. Kidney Int., 15, 335-345, 1979.

27) Jao, W., Manaligod, J.R., Gerardo, L.T. and castillo, M.M.: Myeloid bodies in drug-induced acute tubular necrosis. J. Pathology, 139, 33-40, 1983.

28）百瀬俊郎：急性腎不全の発生病理。日泌尿会誌, 60, 823-833, 1969.

（1983年 4 月 9 日受付，特別掲載） 